\title{
PERANCANGAN SISTEM INFORMASI PEMBUATAN PASS BANDARA BERBASIS WEB PADA PT. ANGKASA PURA I SEMARANG
}

\author{
Wibowo Wicaksono $^{1}$, Ardytha Luthfiarta ${ }^{2}$, Hasan Shobri ${ }^{3}$ \\ 1,2Universitas Dian Nuswantoro; Jl. Imam Bonjol No. 207, Telp: (024) 351.7261, Fax: (024) \\ 356.9684, ${ }^{3}$ Jurusan Teknik Informatika, FIK UDINUS, Semarang \\ e-mail: ${ }^{1}$ wicaksono.mkom@gmail.com, ${ }^{2}$ ardytha.luthfiarta@dsn.dinus.ac.id, \\ 3hasan.shobri@gmail.com
}

\begin{abstract}
Abstrak
PT. Angkasa Pura I (Persero) Cabang Bandara Internasional Ahmad Yani Semarang ini adalah salah satu Badan Usaha Milik Negara yang bergerak di bidang kebandarudaraan. Pada PT. Angkasa Pura I (Persero) Cabang Bandara Internasional Ahmad Yani Semarang terdapat sebuah bidang bernama ITC (Information Technology and Communication) bagian yang menangani yang salah satu tugasnya adalah Menyiapkan dan melakukan kegiatan pengoperasian, pemeliharaan dan pelaporan fasilitas IT. PT. Angkasa Pura I (Persero) Cabang Bandara Internasional Ahmad Yani Semarang yang menjadi tempat penulis dalam melakukan penelitian untuk proses pembuatan pass bandara baru yang masih dilakukan secara manual. Maka untuk mempermudah dan meningkatkan efisiensi pekerjaan penulis membangun sebuah sistem informasi berbasis web yang mengatur proses pembuatan pass bandara baru.
\end{abstract}

Kata kunci: sistem pass bandara baru, Bandara Ahmad Yani, informatika.

\section{PENDAhuluan}

\section{a. Latar Belakang}

PT. Angkasa Pura I (Persero) adalah sebuah perusahaan Badan Usaha Milik Negara yang memberikan pelayanan lalu lintas udara dan bisnis bandar udara di Indonesia yang menitik beratkan pelayanan pada kawasan Indonesia bagian tengah dan kawasan Indonesia bagian timur. PT. Angkasa Pura I mengelola banyak bandar udara di Indonesia, salah satunya di Bandara Ahmad Yani Semarang.

PT. Angkasa Pura I Semarang mengelola proses bisnis dalam pembuatan pass bandara. Pass ini digunakan oleh pihak personal atau perwakilan instansi tertentu yang membutuhkan ijin untuk memasuki zona tertentu di bandara dalam rangka menjalankan segala aktivitas di bandara terkait. Unit Airport Operation \& Service, Airport Security \& Safety dan Sales adalah 3 unit yang berperan dalam alur pembuatan pass bandara di Bandara Ahmad Yani.

Dalam rangka meningkatkan keamanan di Bandar udara, telah ditetapkan Peraturan Menteri Perhubungan Nomor PM 167 Tahun 2015 yang merupakan perubahan atas Peraturan Menteri Perhubungan Nomor PM 33 Tahun 2015 tentang Pengendalian Jalan Masuk (Access Control) ke Daerah Keamanan Terbatas di Bandar Udara. Didalamnya terdapat beberapa pasal yang mengatur tentang daerah keamanan bandar udara, pengendalian jalan masuk ke bandar udara dan sanksi administratif bagi yang melanggar aturan keamanan bandar udara.

Perubahan dari PM 33 Tahun 2015 tersebut adalah untuk memperketat pengawasan dari penggunaan kartu pass bandara agar pemakaiannya sesuai dengan prosedur yang berlaku. Berdasarkan PM 167 tahun 2015, penggunaan pass bandara harus sesuai dengan wilayah kerja dari para pengguna dan dibedakan menjadi tiga latar belakang warna pass sesuai dengan wilayah kerja pengguna pass bandara. Selain itu, penggunaan kartu pass Bandara Ahmad Yani hanya berlaku di wilayah kerja Bandara Ahmad Yani, dan tidak berlaku penggunaannya di bandara-bandara lain, dan demikian juga sebaliknya.

Pass bandara dengan latar belakang warna dasar merah diperuntukkan bagi personel yang melaksanakan tugas sehari-harinya di dominan sisi udara bandar udara, sedangkan latar belakang warna dasar kuning diperuntukkan bagi personel yang melaksanakan tugas sehari-harinya dominan di terminal 
penumpang bandar udara dan latar belakang warna dasar biru diperuntukkan bagi personel dari instansi/institusi yang melaksanakan tugas sehari-harinya dominan di luar daerah keamanan terbatas bandar udara.

\section{b. Rumusan Masalah}

Berdasarkan latar belakang yang sudah dipaparkan diatas dapat dirumuskan masalah dalam penelitian ini adalah Bagaimana merancang Sistem Informasi Pembuatan Pass Bandara Ahmad Yani Semarang yang terintegrasi.

\section{c. Tujuan}

1) Tujuan dari penelitian yang dilakukan penulis adalah sebagai berikut :

1) Mengotomatisasi proses pembuatan pass bandara baru Bandar Udara Ahmad Yani Semarang

2) Merancang basis data dengan baik untuk Sistem Informasi Pembuatan Pass Bandara

\section{PERANCANGAN SISTEM}

\section{a. Kebutuhan Sistem}

1) Software yang digunakan

Penulis menggunakan beberapa software untuk membuat aplikasi berbasis web. Adapun beberapa software yang digunakan yaitu :

a) macOS High Sierra

macOS High Sierra sebagai sistem operasi

b) PHPStorm 2018.1.5

PHPStorm sebagai integrated development environment (IDE) yang digunakan untuk mengembangkan aplikasi berbasis PHP.

c) Xampp

XAMPP digunakan untuk manajemen database phpMyadmin.

d) PhpMyAdmin V.4.3.11

PhpMyAdmin digunakan sebagai tools yang digunakan untuk mengatur administrasi MySQL.

e) Datagrip 2018.1.4

Datagrip digunakan sebagai tools yang digunakan untuk mengatur administrasi MySQL.

f) Google Chrome

Google chrome digunakan sebagai browser utama untuk debugging

g) Composer

Composer digunakan sebagai dependency manager untuk pengembangan aplikasi PHP

2) Hardware yang Digunakan

Tabel 1. Hardware yang dibutuhkan mengembangkan aplikasi pass bandara

\begin{tabular}{|l|l|c|}
\hline No & Nama Hardware & Keterangan \\
\hline 1. & Laptop & RAM 8 GB, CPU Intel i5 \\
\hline
\end{tabular}




\section{b. Perancangan Sistem}

1) Flowchart dan alur system
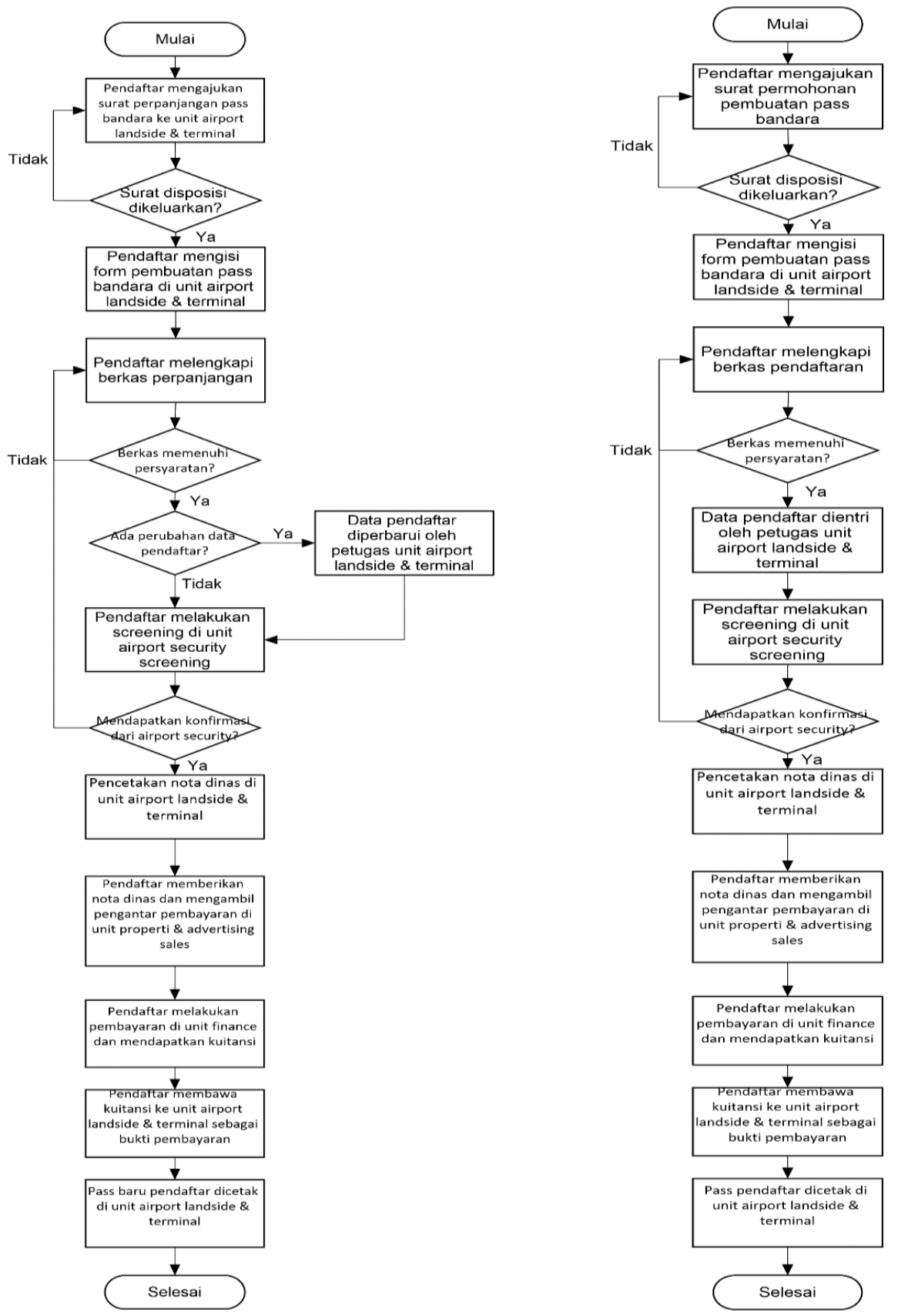

Gambar 1 Flowchart Pengajuan dan Pembaruan pass Bandara

2) Table Diagram

Tabel diagram merupakan proses implementasi pembuatan aplikasi, berikut ini adalah perancangan tabel diagram yang dibutuhkan pada system: 


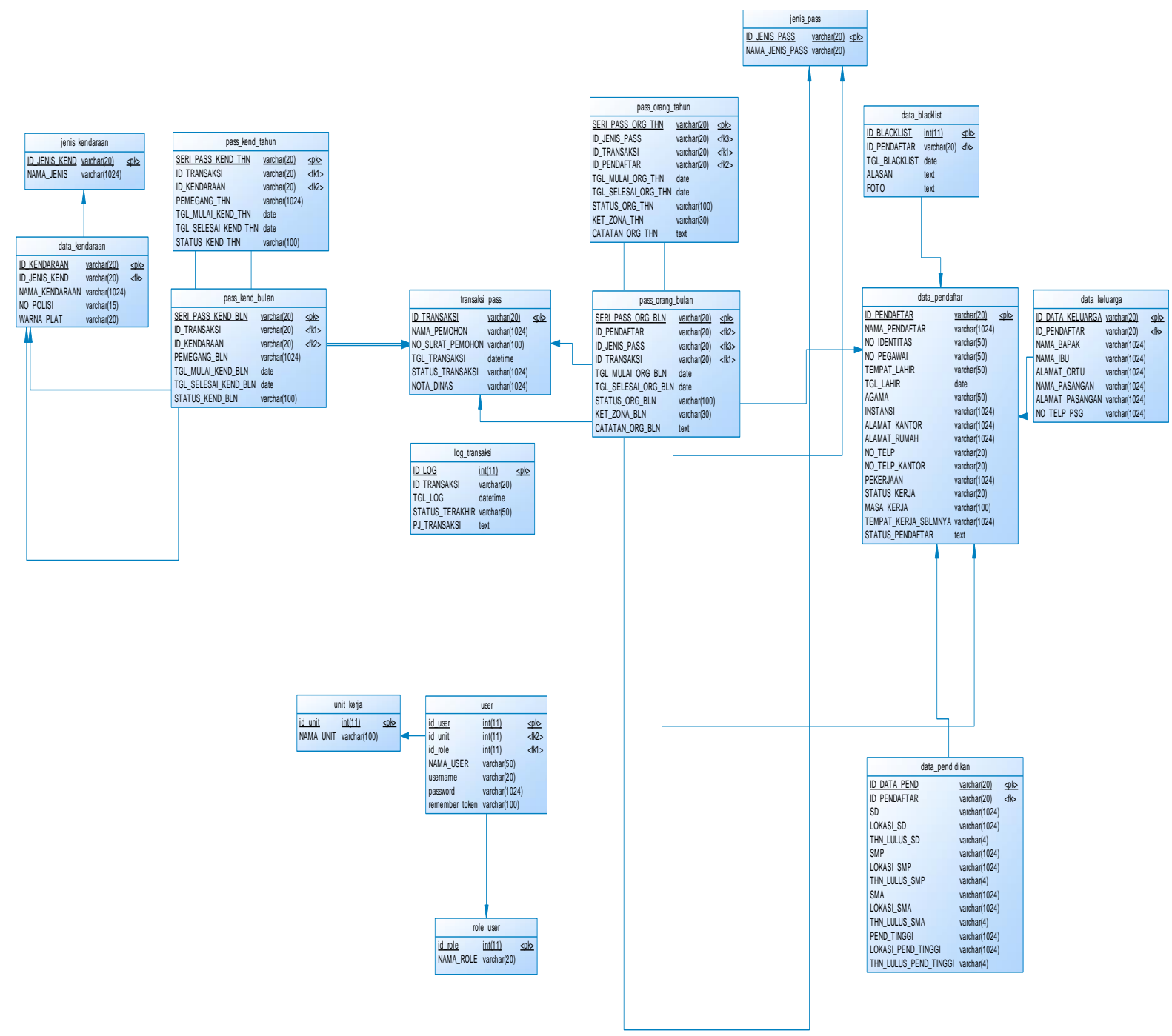

Gambar 2. Relasi Table pada Database

3) Use Case Diagram

Dalam use case ini di gambarkan bagaimana seluruh aktor yang berperan dalam penggunaan SIPABBAN. Aktor dibagi menjadi 4, yaitu Pemohon pass, super admin, admin dan user. Pemohon pass dapat melakukan pengajuan pass baru. Super admin dapat melihat user, melihat pengajuan pass, melihat log transaksi, melihat pendaftar, melijat laporan dan melihat daftar black list. Admin dapat melakukan semua yang dilakukan oleh super admin kecuali management user. Sedangkan user hanya dapat melihat log transaksi, melihat laporan dan melihat daftar blacklist. 


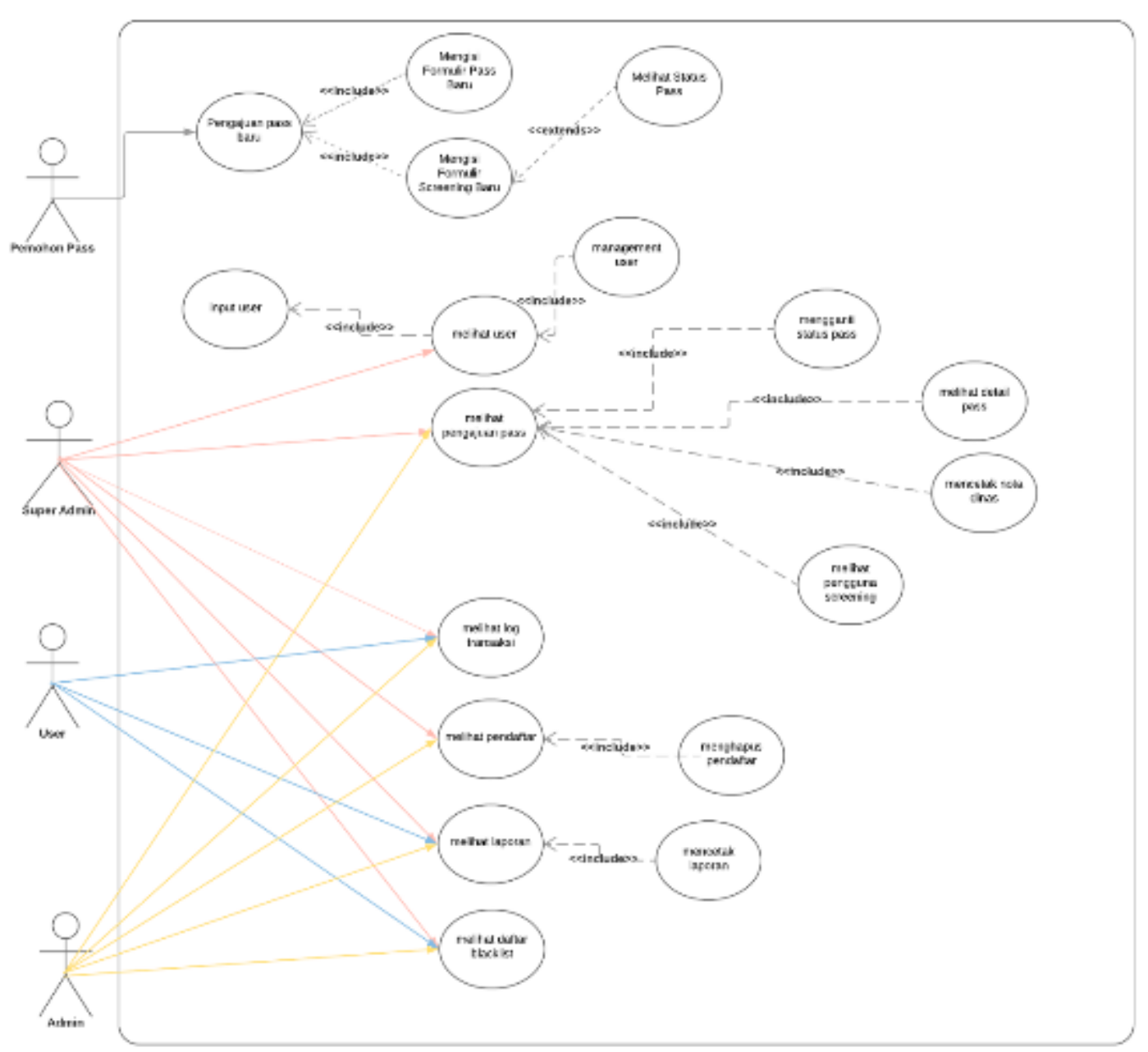

Gambar 3. Use Case diagram

\section{4) Activity Diagram}

Activity diagram digunakan untuk menggambarkan kegiatan-kegiatan yang ada pada suatu system yang sedang berjalan, bentuk persegi menggambarkan suatu fungsi tertentu yang ada dalam system, tanda panah menggambarkan aliran di dalam system dan belah ketupat menggambarkan keputusankeputusan bercabang.

Pada Activity Diagram tersebut bahwa aktor pada aktivitas ini adalah user, dalam hal ini user melakukan permintaan untuk melakukan pengajuan pass bandara baru. Pertama user akan melakukan permintaan pengajuan pass dengan membuka menu pass baru, dan sistem akan otomatis membuatkan nomor id unik yang bisa digunakan untuk mengidentifikasi transaksi. Setelah itu pengguna dapat memasukkan nama pemohon pass dan juga nomor pengajuan pass. Satu ID pengajuan pass dapat digunakan untuk beberapa pemohon pass sekaligus. Setelah itu pemohon dapat mengisi identitas dan mengunggah berkas yang dibutuhkan. Jika sudah selesai, pengguna dapat menambahkan pemohon kedua dan seterusnya. 
Tabel 2. Activity Diagram Pengajuan Pass Bandara Baru

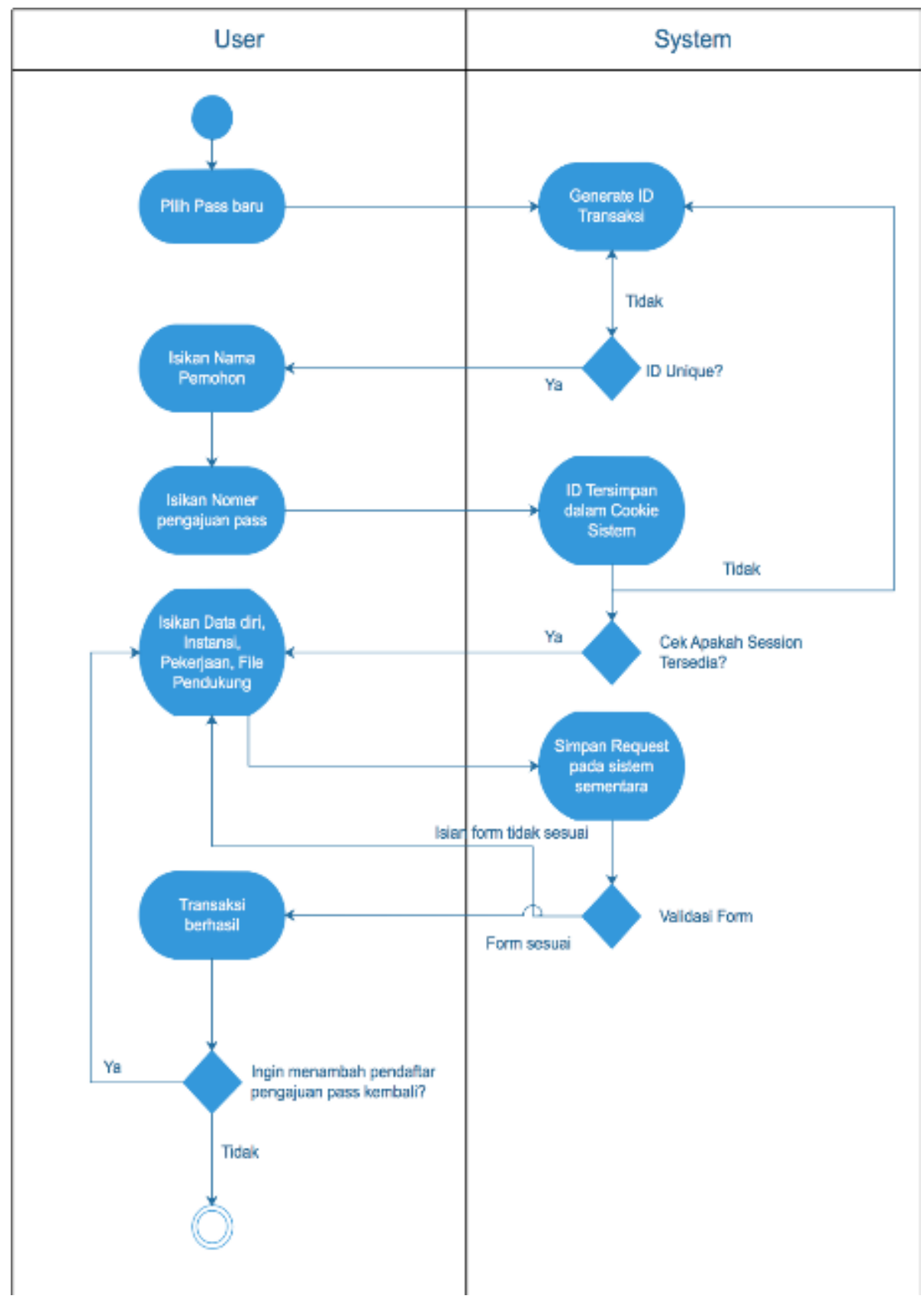


Tabel 3. Activity Diagram Screening Pass Baru

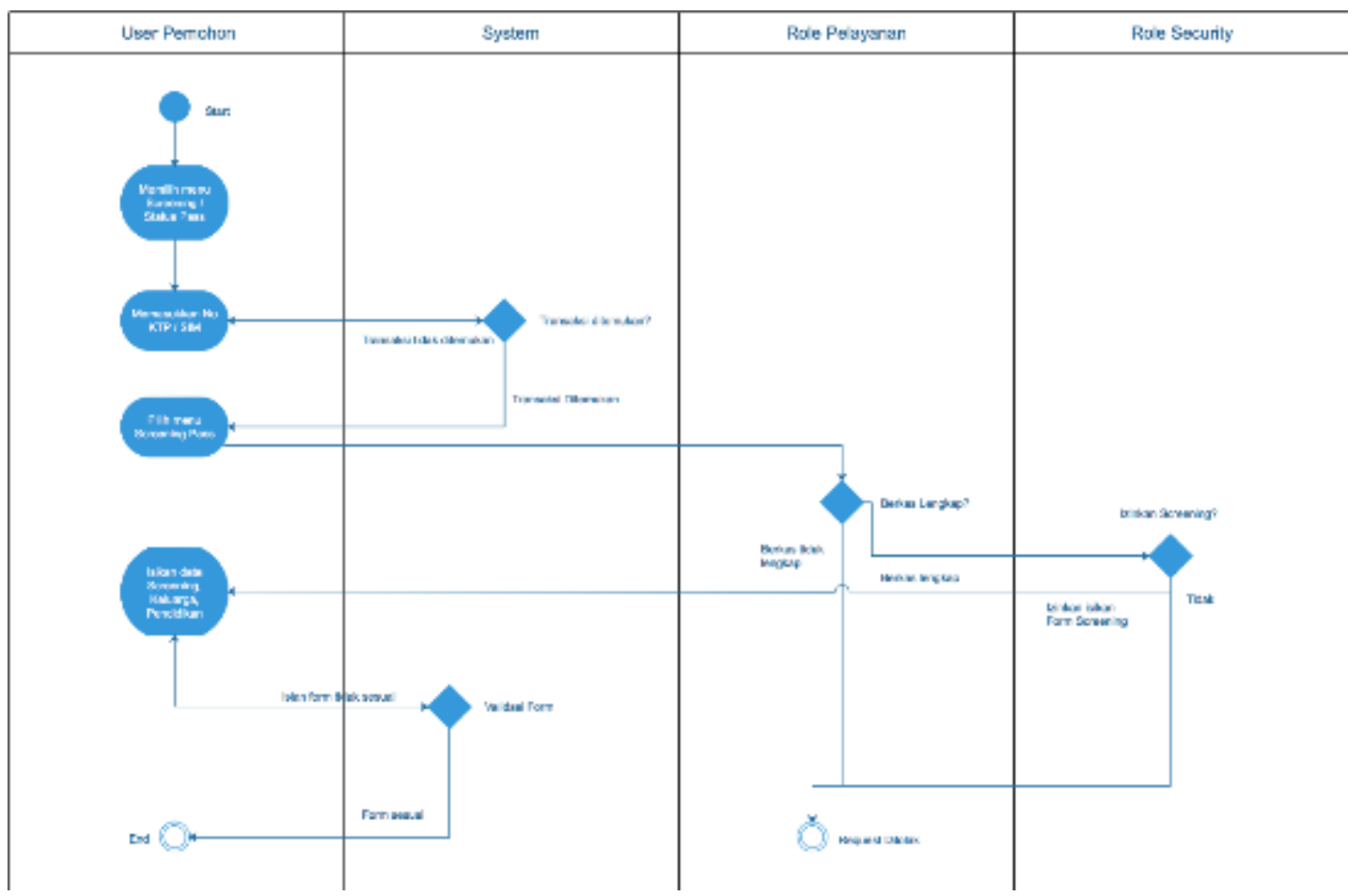

Pada Activity Diagram tersebut bahwa aktor pada aktivitas ini adalah user pemohon, admin pelayanan dan admin bagian security. Dalam diagram ini dijelaskan alur user dalam melakukan proses pengisian form screening pass bandara. Pertama user menggunakan menu screening pass untuk pengisian formulir screening. User diharuskan untuk mengisikan nomor identitas untuk mengetahui transaksi user tersebut. Jika transaksi ditemukan user akan diarahkan ke dashboard screening. Pengguna dapat melakukan screening dengan syarat sudah melengkapi berkas dengan konfirmasi dengan pelayanan dan diizinkan mengisi screening form setelah meminta konfirmasi dengan security. Jika salah satu aspek tersebut belum terpenuhi maka sistem akan menolak transaksi pengisian screening form.

\section{IMPLEMENTASI PROGRAM}

Sistem ini akan digunakan oleh 3 unit terkait, dengan unit IT sebagai super admin yang mengelola keseluruhan sistem. Pembangunan sistem ini dimulai dari pengumpulan data dan wawancara dengan 3 unit terkait, perancangan fungsionalitas dan basis data, pembuatan fungsionalitas dengan framework Laravel 5.3 dan tampilan web, terakhir adalah presentasi dan uji coba.

Untuk pembangunan SIPPABAN ini dibagi menjadi 2 bagian yaitu front-end dan back-end, bagian yang dikerjakan penulis adalah bagian front-end dan beberapa fitur yang akan dipaparkan sebagai berikut:

1) Halaman utama SIPPABAN

Halaman utama menampilkan 4 menu utama. Pendaftaran Pass, Pelayanan Administrasi, Airport Security \& Safety, dan Sales. Pendaftaran Pass diakses oleh pengguna umum sedangan 3 menu lainnya digunakan oleh masing-masing unit terkait dan membutuhkan autentikasi login.

2) Dashboard

Halaman untuk input mandiri dan melakukan pengecekan status pass

3) Input data transaksi pass

Pada fitur input transaksi pass, pengguna yang akan mendaftarkan pass bandara menginputkan nama pemohon yang biasanya mewakili instansi tertentu, nomor surat permohonan dari instansi dan memilih keperluan pendaftaran. Jika mendaftar baru maka akan diarahkan ke input data pendaftar, jika perpanjangan maka diarahkan ke daftar data pendaftar yang sudah ada. 
4) Input data pendaftar \& pass orang

Pada fitur ini, menggunakan tab pendaftar halaman input pass, pengguna yang akan mendaftarkan pass orang menginputkan nama pendaftar, nomor identitas, nomor pegawai, tempat lahir, tanggal lahir, agama, instansi, alamat rumah, alamat kantor, nomor telepon, nomor telepon kantor, pekerjaan, status kerja, masa kerja, tempat kerja sebelumnya sebagai data pendaftar dan memilih periode pass yaitu bulanan atau tahunan serta menginputkan tanggal mulai dan selesai pass orang.

5) Perpanjangan pass

Untuk perpanjangan pass tidak berbeda dengan input transaksi pass, yang membedakan hanya ketika data pendaftar dan/atau kendaran sudah ada dan ingin melakukan pembaruan data maka dapat dilakukan dengan fitur ini. Karena perpanjangan pada dasarnya adalah pembuatan pass baru dengan masa berlaku yang berbeda menggunakan data pendaftar yang sudah ada. Pengguna cukup menginputkan periode pass yaitu bulanan atau tahunan serta menginputkan tanggal mulai dan selesai pass.

6) Input data keluarga

Pada fitur ini, saat tahap screening di unit Airport Security \& Safety, pengguna yang akan mendaftarkan pass bandara menginputkan nama bapak, nama ibu, alamat orangtua, nama pasangan, alamat pasangan, nomor telepon pasangan.

7) Input data pendidikan

Pada fitur ini, saat tahap screening di unit Airport Security \& Safety, pengguna yang akan mendaftarkan pass bandara menginputkan SD, lokasi SD, tahun lulus SD, SMP, lokasi SMP, tahun lulus SMP, SMA, lokasi SMA, tahun lulus SMA, pendidikan tinggi, lokasi pendidikan tinggi, tahun lulus pendidikan tinggi.

8) Data master blacklist

Pada data master ini, dapat menampilkan seluruh data blacklist yang ada. Unit Airport Security \& Safety dapat menginputkan data blacklist dengan memilih data pendaftar dan memasukkan tanggal blacklist dan alasannya. Status pendaftar pun diubah dari terdaftar menjadi blacklist. Selain itu data blacklist juga dapat dihapus dan mengubah status pendaftar kembali menjadi semula.

9) Data master pendaftar

Pada data master ini, ditampilkan seluruh data pendaftar yang ada. Unit Airport Landing dapat memperbarui data pendaftar sesuai keperluan.

10) Tampil pass orang yang akan habis masa berlakunya

Pada fitur ini, dapat menampilkan seluruh data pass orang untuk periode bulanan dan tahunan yang akan habis masa berlakunya dalam kurun waktu seminggu. Fitur ini digunakan oleh Airport Operation \& Service dan Airport Security \& Safety sehingga dapat menginformasikan kepada pendaftar dan mengambil tindakan jika ada yang melanggar.

11) Laporan pembuatan pass pada bulan tertentu dan tahun tertentu

Pada fitur ini dapat menampilkan jumlah transaksi, jumlah pendaftar pada bulan tertentu. Menampilkan detil berupa pass orang untuk periode bulanan dan tahunan untuk periode bulanan dan tahunan pada bulan dan tahun yang dipilih.

\section{a. Halaman Utama SIPABBAN}

Halaman Utama portal Sipabban, halaman di desain untuk perangkat layar sentuh dikarenakan pada implementasi SIPABBAN akan dilakukan pada perangkat layar sentuh. Pada Halaman Utama terdapat 3 menu, Pass Baru untuk melakukan pendaftaran Pass baru, Perpanjangan pass untuk melakukan perpanjang pass yang sudah ada, Screening pass untuk melakukan screening dan pengisian form screening. 


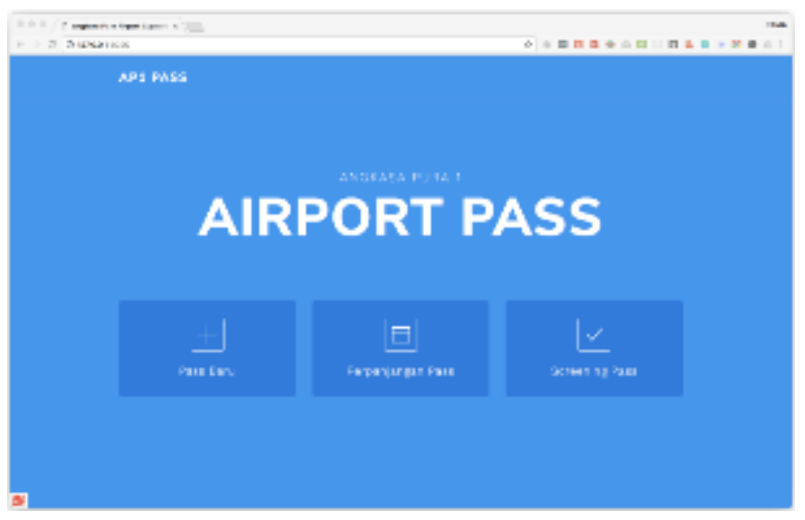

Gambar 4. Tampilan Halaman Utama SIPABBAN

\section{b. Halaman Utama Pass Baru}

Pada halaman ini terdapat form yang harus diisi oleh Pendaftar Pass Bandara. Terdapat 1 buah field ID yang akan terisi otomatis, field ini bergungsi sebagai ID unik yang akan mengidentifikasi setiap transaksi yang dibuat. Pengguna diwajibkan untuk mengisi nama pemohon dan Nomor surat pengajuan sebagai syarat untuk mendaftar pass bandara baru

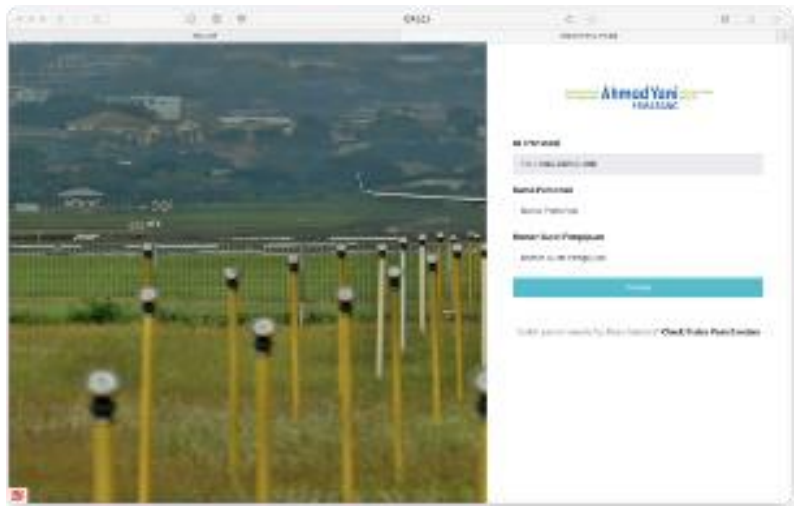

Gambar 5. Tampilan Awal Pass Baru

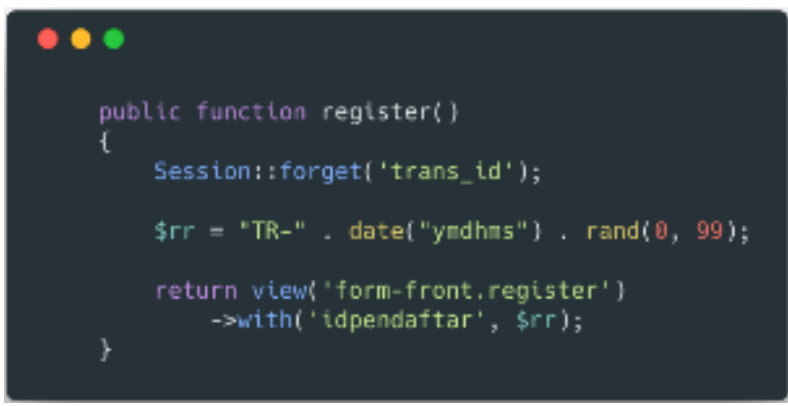

Gambar 6. Fungsi Register Controller

Pada controller ini dijelaskan proses membuat kode transaksi pass secara otomatis berdasarkan tanggal pembuatan dan juga angka acak. Hal ini bertujuan agar tidak ada transaksi pass dengan nomor id yang sama

c. Halaman Formulir pengajuan pass bandara baru

Setelah melakukan pengisian formulir awal pengajuan pass, pengguna akan diarahkan untuk mengisi formulir secara lengkap untuk melakukan pengajuan pass. Pada halaman ini, satu ID pengajuan dapat menampung beberapa user untuk pengajuan pass bandara baru. 


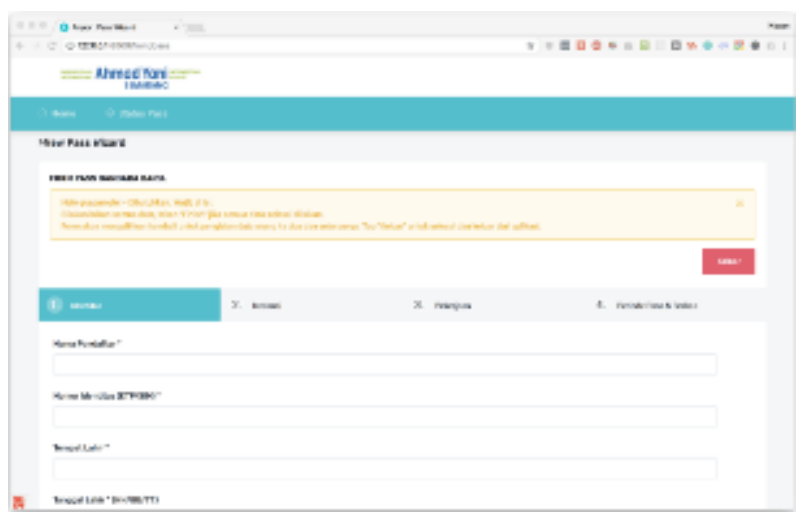

Gambar 7. Halaman formulir pengajuan pass bandara baru

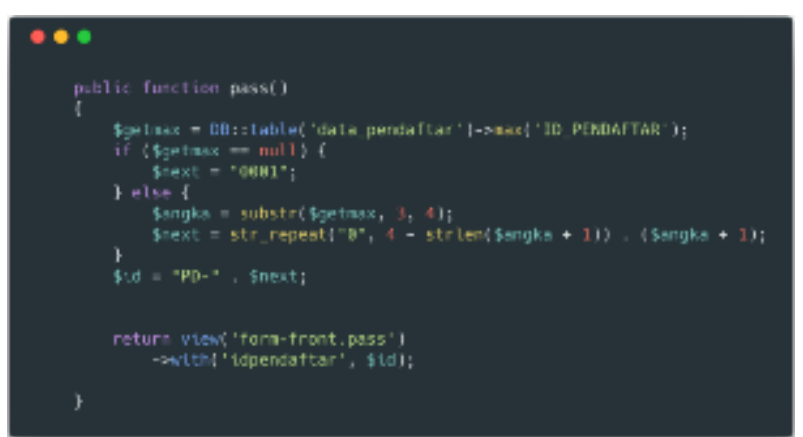

Gambar 8. Pass Controller

Controller Pass menjelaskan bagaimana sistem membuat nomor id registrasi per orang.

d. Halaman Status Pass

Halaman ini digunakan pengguna untuk melakukan pengecekan status pass. Pada halaman ini pengguna juga dapat melakukan pengajuan screening pass. Pengguna dapat melakukan pengecekan dengan menggunakan NIK / SIM.

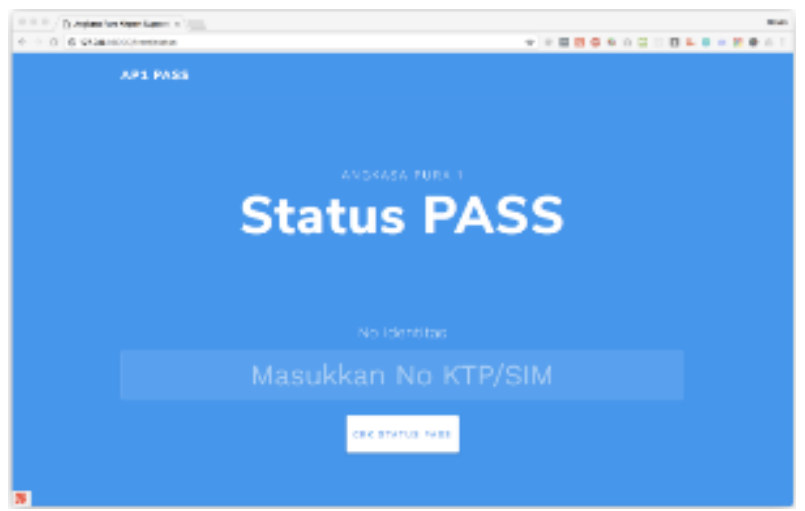

Gambar 9. Halaman awal Status Pass Bandara

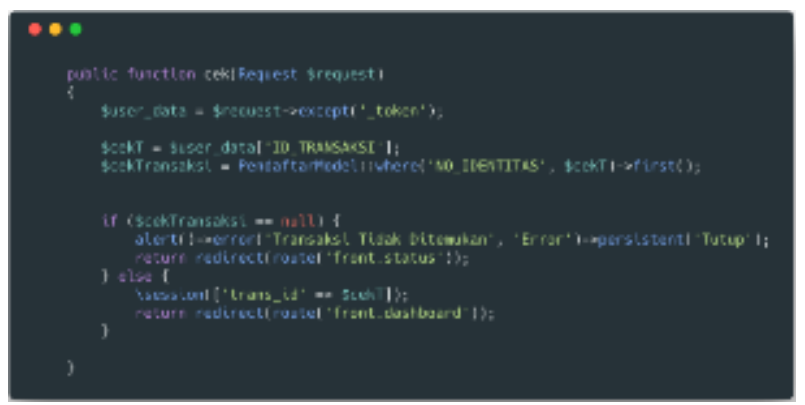

Gambar 10. Controller untuk cek status Screening 
Controller FrontController@cek bertujuan untuk melakukan pengecekan status screening berdasarkan Nomor identitas dari setiap pemohon screening.

e. Halaman Detail Status Pass

Pada halaman ini pengguna dapat melakukan pengajuan screening pass bandara baru

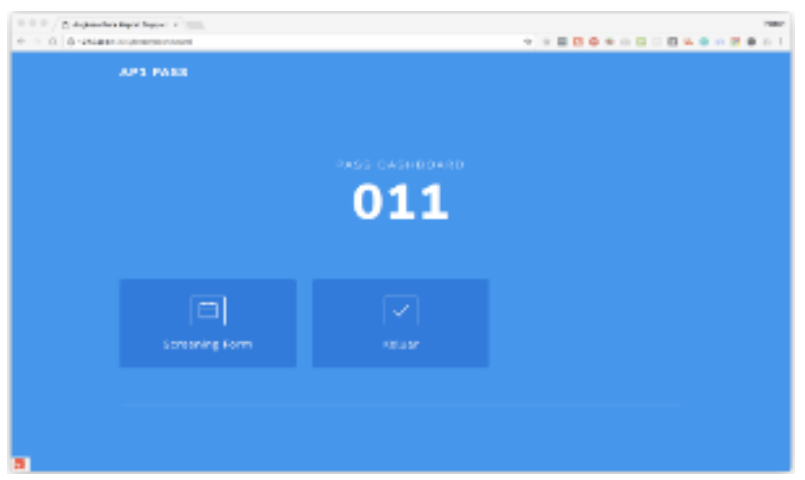

Gambar 11. Halaman Pengguna Status Pass

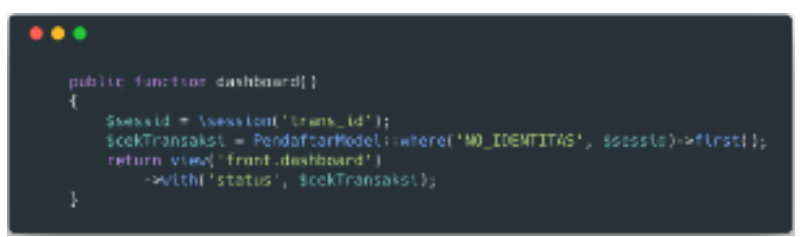

Gambar 12. Controller pada Dashboard

Controller FrontController@dashboard adalah controller untuk menampilkan tampilan dashboard pemohon pass bandara. Menggunakan session untuk memudahkan system bernavigasi.

\section{f. Halaman Formulir Screening Pengguna}

Pada halaman ini, pengguna diwajibkan untuk mengisi formulir screening yang disediakan. Formulir screening meliputi Data Keluarga dan data pendidikan, Formulir screening bisa di akses oleh pengguna setelah Divisi Security Bandara memperbolehkan pengguna untuk melakukan screening.

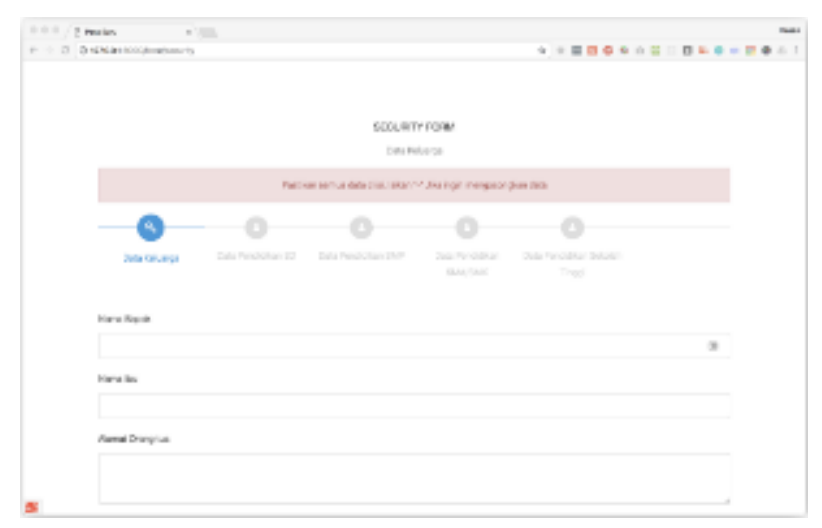

Gambar 13. Formulir Screening Pemohon



Gambar 14. Cuplikan Source code Screening Form 
Controller ini berfungsi sebagai controller pada form screening. Pada form screening menggunakan session sebagai id untuk menunjukkan pemohon.

g. Halaman Login Administrasi

Halaman Login diperuntukkan untuk administrator. Untuk dapat melakukan autentikasi pengguna administrasi diharuskan untuk mempunyai akun meliputi ID dan password. Halaman login administrasi bersifat tertutup.

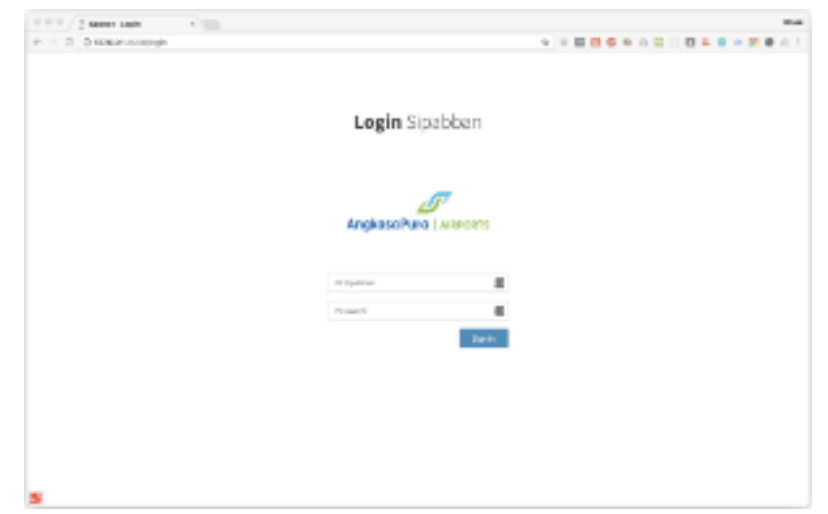

Gambar 15. Halaman Login Administrasi Pass Bandara

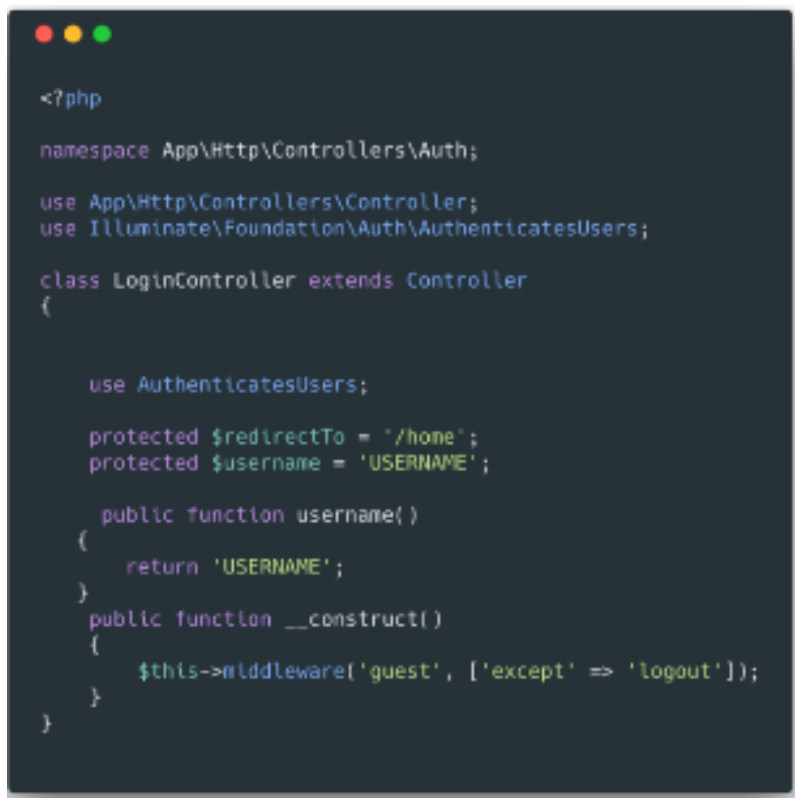

Gambar 16. Controller user login

Pada controller ini dijelaskan proses untuk login. Pada login menggunakan username dan juga password untuk melakukan authentikasi.

\section{h. Halaman Dashboard Administrasi}

Halaman dashboard administrasi di batasi dengan role pengguna dan unit kerja pada aplikasi Pass Bandara. Role pengguna dibagi menjadi 3 yaitu Super Admin, Admin dan User. Unit kerja di bagi menjadi 4 yaitu ICT, Pelayanan, Security dan Sales. Tiap role dan unit kerja mempunyai hak akses sendiri-sendiri dalam menggunakan system. 




Gambar 17. Halaman Dashboard dan Daftar user Administrasi Pass Bandara

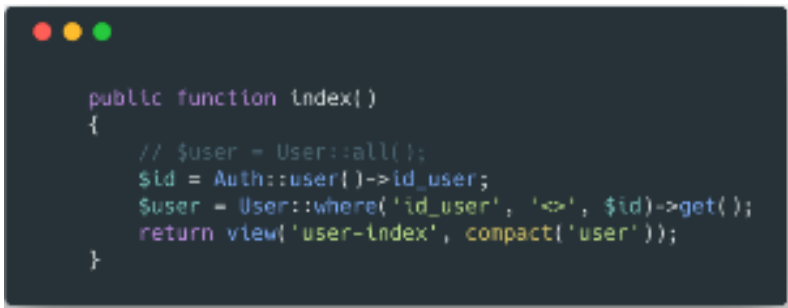

Gambar 18. Controller admin dashboard

i. Halaman Transaksi Pass Bandara



Gambar 19. Tampilan Halaman Pengajuan Pass

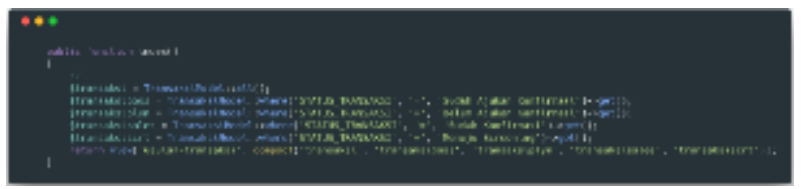

Gambar 20. Cuplikan source code daftar pengajuan pass

Halaman Transaksi digunakan untuk menampilkan daftar transaksi yang sedang berjalan dan transaksi yang telah berjalan. Penampilan record akan dibedakan menjadi beberapa warna diantaranya:

- Warna abu-abu menunjukkan jika transaksi memasuki tahap screening

- Warna kuning jingga menunjukkan jika transaksi baru masuk dan belum mendapatkan konfirmasi dari pelayanan

- Warna merah menandakan jika pass sudah melakukan screening dan melanjutkan ke tahap selanjutnya.

j. Halaman Detail Pendaftar

Pada tampilan detil pendaftar ini ditampilkan data pribadi pendaftar, data keluarga, dan data pendidikan pendaftar yang sudah diinputkan pada tahap screening. 
Unit Airport Landing juga dapat memperbarui data pendaftar sesuai keperluan. Petugas menekan ikon edit pada data pendaftar, maka tampilan berpindah ke tampilan untuk mengedit data pribadi pendaftar. Setelah data pribadi diubah, maka petugas menekan tombol "Simpan" dan tampilan kembali ke data master pendaftar.

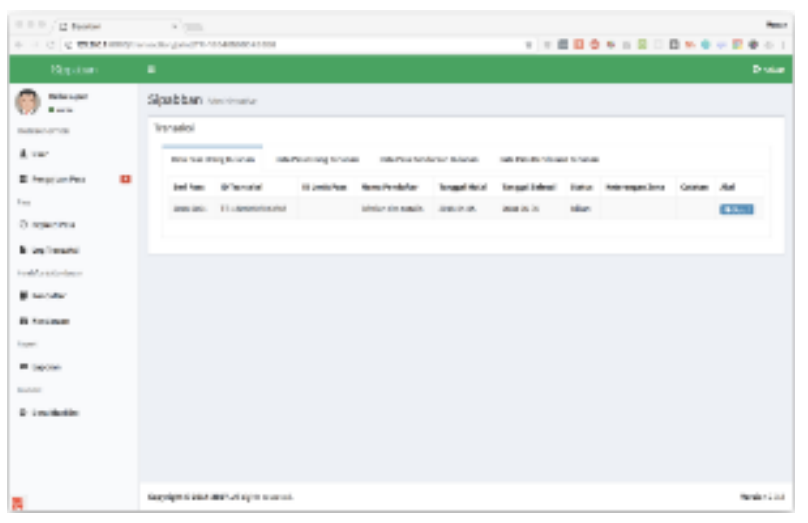

Gambar 21. Halaman Detail Pendaftar

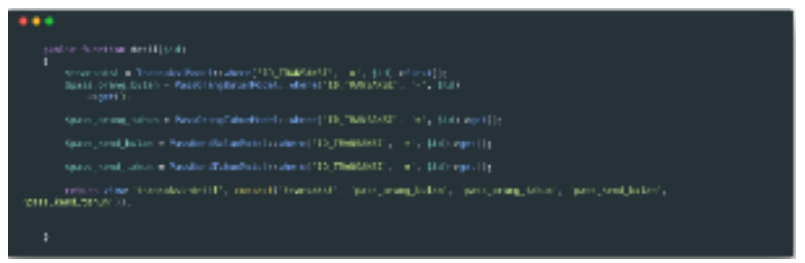

Gambar 22. Cuplikan source code Detail Transaksi

\section{k. Halaman Expired Pass}

Expired Pass digunakan untuk mengidentifikasi pass bandara yang hampir kadaluarsa atau habis masa aktifnya.

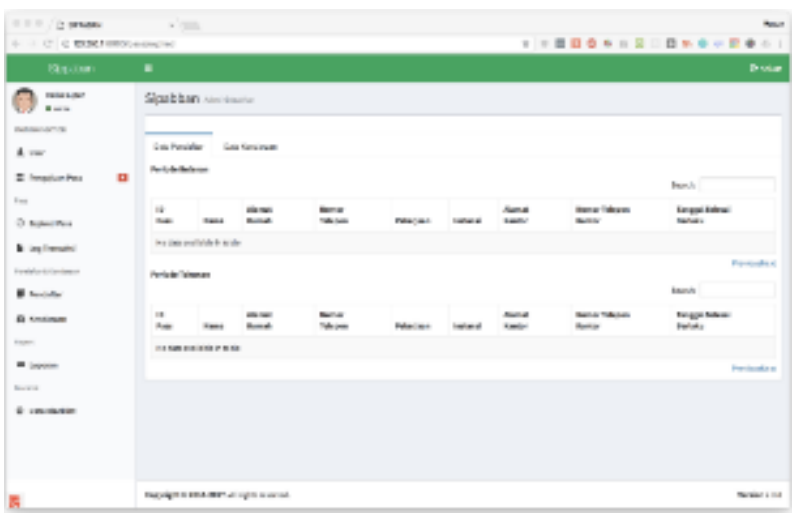

Gambar 23. Halaman Expired Pass

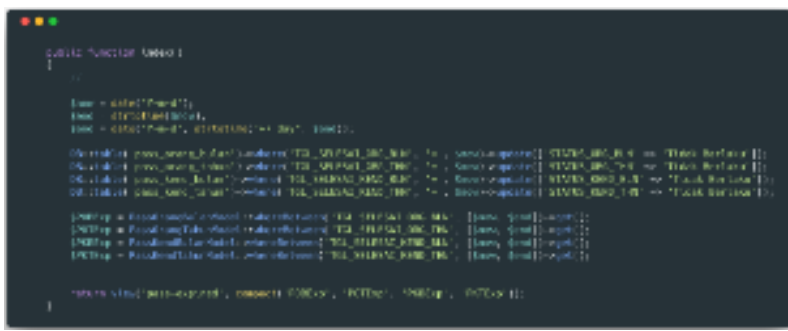

Gambar 24. Cuplikan Source code ExpiredPassController 
1. Halaman Log Transaksi

Log Transaksi digunakan untuk melakukan pengecekan tentang perubahan aktivitas pada pengajuan, screening pass bandara. Pada halaman ini semua aktivitas terkait transaksi pass bandara akan terekam.

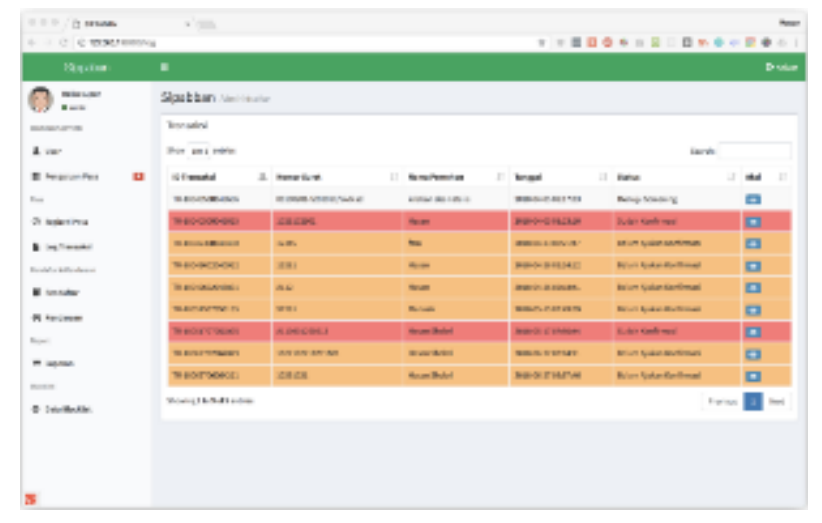

Gambar 25. Log Pass Bandara

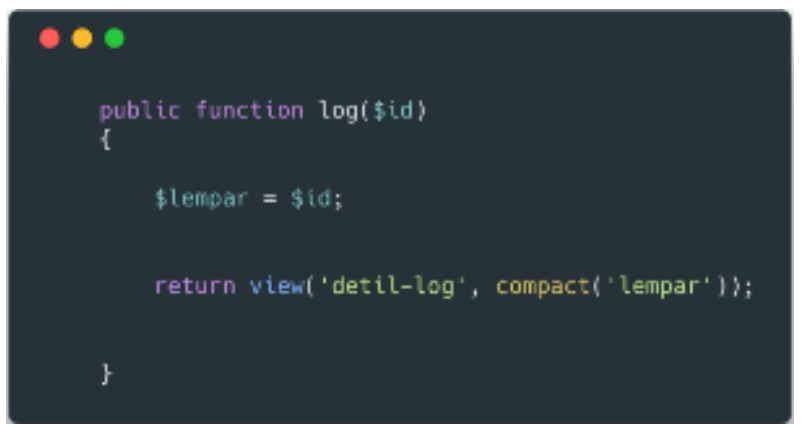

Gambar 26. Cuplikan source code fungsi penampilan log

m. Halaman Data Pendaftar

Data master menampilkan seluruh data pendaftar yang ada. Petugas dapat melihat detil dari data pendaftar dengan menekan ikon berbentuk mata pada data pendaftar.

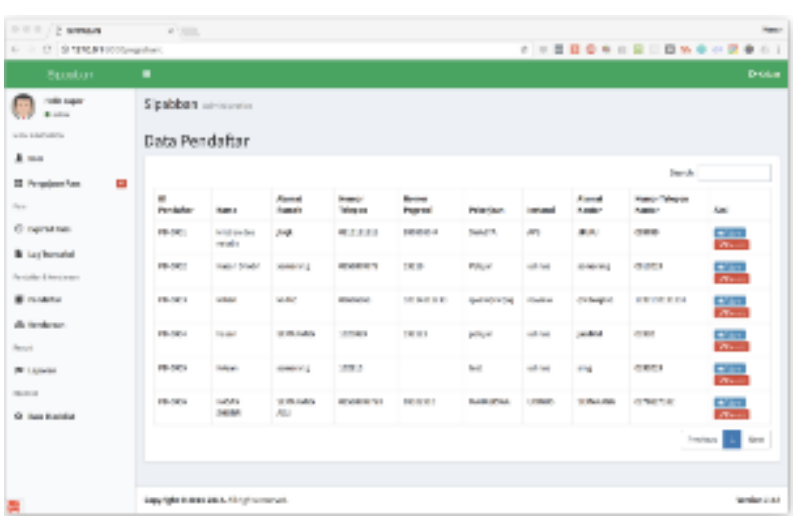

Gambar 27. Halaman Data Pendaftar 


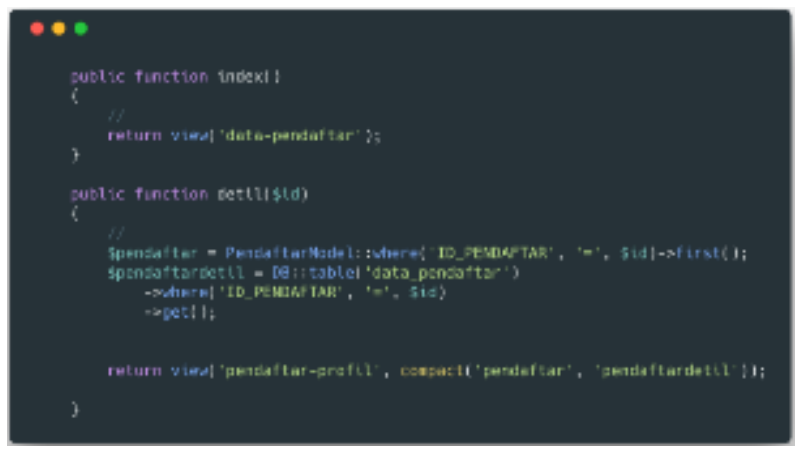

Gambar 28. Halaman controller untuk penampilan data pemohon

n. Halaman Data Blacklist

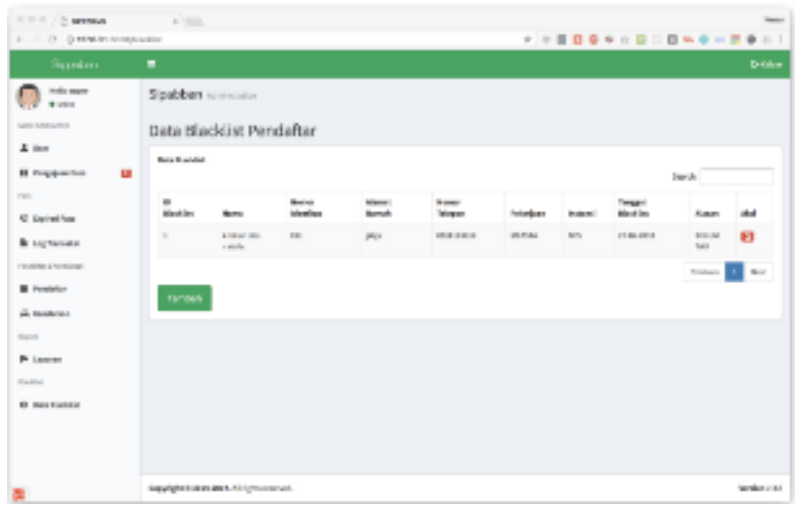

Gambar 29. Halaman Data Blacklist

Data master ini digunakan oleh unit Airport Operation \& Service dan unit Airport Security \& Safety. Data master dapat menampilkan seluruh data blacklist yang ada. Unit yang menggunakan dapat menginputkan data blacklist dengan menekan tombol "Tambah", kemudian tampilan berpindah ke daftar pendaftar.

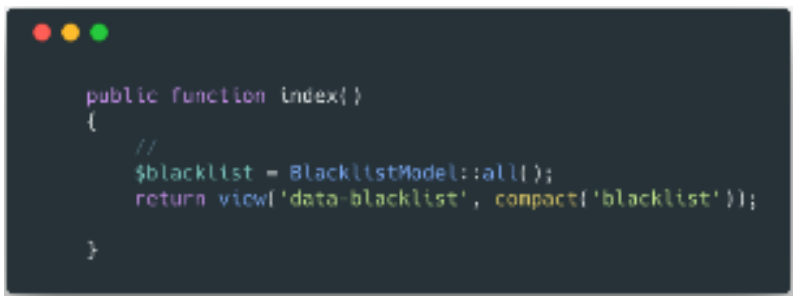

Gambar 30. Cuplikan source code untuk fungsi penampilan daftar hitam

Petugas memilih data pendaftar dengan menekan tombol "Blacklist" pada data pendaftar yang dipilih dan akan muncul pop-up konfirmasi. Jika "Ya" maka tampilan berpindah ke tampilan data lengkap pendaftar, petugas memasukkan tanggal blacklist dan alasannya. Kemudian petugas menyimpan data blacklist dengan menekan tombol "Blacklist". Status pendaftar pada data pendaftar diubah dari "Terdaftar" menjadi "Blacklist".

o. Halaman Cetak Nota dinas

Halaman ini berfungsi sebagai halaman untuk mencetak nota dinas tiap transaksi. 




Gambar 31. Halaman Cetak Nota Dinas

\section{KESIMPULAN}

Berdasarkan penelitian yang telah dilakukan mengenai perancangan dan implementasi aplikasi Sistem Informasi Pass Bandara, maka dapat ditarik kesimpulan sebagai berikut :

a. Sistem SIPABBAN dapat membantu dalam management alur pembuatan pass bandara baru, pemberkasan, dan screening pass bandara.

b. Sistem SIPABBAN diharapkan dapat menjadi kios mandiri dalam pembuatan dan pengajuan Pass bandara baru

\section{SARAN}

Bedasarkan kesimpulan yang telah dipaparkan, masih diperlukan adanya perbaikan dari segi module, keamanan dan juga tampilan guna menjaga kenyamanan penggunaan sehingga performa sistem dapat meningkat. Penanganan error juga dapat dijelaskan karena sistem ini diharapkan akan menjadi sistem mandiri, yang dimana pengguna pengajuan pass baru dapat menggunakan dan mengoperasikan sistem secara mandiri.

\section{DAFTAR PUSTAKA}

[1] H. SRG/Hpr, "Pass Bandara Diperketat Untuk Pengendalian Jalan Masuk Ke Daerah Keamanan Terbatas," PT. Angkasa Pura I, 10 Februari 2017. [Online]. Available: https://ahmadyaniairport.com/id/berita/index/pass-bandara-diperketat-untuk-pengendalian-jalan-masuk-ke-daerahkeamanan-terbatas. [Accessed 29 Juni 2018].

[2] J. Hutahaean, Konsep Sistem Informasi, Sistem Informasi, 2015.

[3] Jogiyanto, Analisis dan Design, Yogyakarta: Andi Offset, 2005.

[4] E. Siregar, Membangun Aplikasi Berbasis Web ASP.NET 2.0, Andi, 2007.

[5] M. R. Arif, "Pemrograman Web Dinamis Menggunakan PHP dan MySQL," 2012.

[6] IDCloudhost, "Pengertian dan Keunggulan Framework Laravel," IDCloudhost, 76 2016. [Online]. Available: https://idcloudhost.com/pengertian-dan-keunggulan-framework-laravel/. [Accessed 22 06 2018].

[7] "pengertian crud: malasngoding," [Online]. Available: http://www.malasngoding.com/tag/pengertian-crud-php/.

[8] "Pangkalan Data - Wikipedia bahasa indonesia, ensiklopedia bebas," Wikipedia, [Online]. Available: https://id.wikipedia.org/wiki/Pangkalan_data. [Accessed 8 Mei 2017].

[9] J. F. Courtney and D. B. Paradice, Database System for Management Third edition, 2010.

[10] M. Kusrini, Perancangan dan Pengolahan Basis Data, Yogyakarta: ANDI, 2007.

[11] "MySQL - wikipedia bahasa indonesia, ensiklopedia bebas," Wikipedia, [Online]. Available: https://id.wikipedia.org/wiki/MySQL. [Accessed 9 Mei 2017].

[12] J. Valade, PHP AND MySQL Web Development, Wiley Publishing, Inc., 2008.

[13] U. L. F. I. Terapan, "Penjgenalan IDE (Integrated Development Environment)," Telkom University, 0803 2017. [Online]. Available: https://fit.labs.telkomuniversity.ac.id/pengenalanide-integrated-development-environment/. [Accessed 2206 2018]. 